\title{
Buscant el camí cap a la creativitat a l'aula de ciències
}

\author{
Anna Torras Galán (tac87@hotmail.com) Universitat Pompeu Fabra (Barcelona).
}

Els adolescents que es troben en un aula escolar són diferents, tenen diverses potencialitats $i$ interessos. Els seus nivells d'atenció també són variats $i$ alguns presenten limitacions significatives en aquest aspecte. Un factor que condiciona la seva atenció és la creativitat per dur a terme una tasca determinada. Per això és important estimular la seva imaginació amb la finalitat de incrementar l' interès i l'autoestima personal. El present article pretén demostrar que fomentar la creativitat és sinònim de despertar la curiositat entre els estudiants. Per fer-ho es presenten un seguit d'activitats i recursos didàctics.

Paraules clau: creativitat, interès, hipòtesis, motivació, didàctica.

Teenagers who are in a classroom school are different; they have several potentialities and interests. Their levels of are varied and some have significant limitations One factor that determines the attention is creativity to carry out a specific task. For this reason, it is important to stimulate their imagination in order to enhance interest and personal selfesteem. The present art ass aims to demonstrate that foster creativity, through activities and resources did practical, is without minimum of arousing the curiosity of the students.

Key words: creativity, interest, hypothesis, motivation, didactic.

\section{INTRODUCCIÓ}

Som donats a concebre la creativitat com alguna cosa acabada ja sigui poesia o pintura o qualsevol altre producte. Deixem així a la imaginació reduïda a la categoria inferior de l'estereotip. Maslow comenta que donem per descomptat que un poeta és més creatiu que un cuiner o que un matemàtic 0 enginyer, perquè al seu producte li hem donat un valor més intel-lectual, més durador, més espiritual, quan en realitat el vàlid no és tant el producte final sinó el procés pel qual el resultat es dóna en l'individu mateix.

La creativitat és un procés de formulació d'hipòtesi, de verificació de les mateixes i de comunicació dels resultats, convertint-se així en un procés investigador que es desenvolupa dins del mateix individu. Descartem des d'aquest punt de partida l'afirmació que hi ha individus que neixen creatius. La personalitat creativa es fa, no neix. Per tant es pot incrementar la imaginació per obtenir una major motivació per part de l'alumnat. La motivació és el sabor en el menjar, és l' ingredient que li dóna el toc especial i únic al que es fa, és el que dóna l'embranzida constant fins al final del que es comença, l'alumnat ha de despertar la seva motivació abans de començar un projecte, per activar aquest motor de força únic en ell perquè no es detingui a la meitat del camí i aconsegueixi conquistar les seves metes.

\section{EXPERIÈNCIA PERSONAL}

Durant el meu període de pràctiques en un IES de Sant Cugat del Vallès (Barcelona), he analitzat alumnes amb necessitats educatives per fomentar la seva imaginació. Aquest estudi, es basa en un cas en particular, el cas d'un noi de 17 anys, estudiant de primer de batxillerat científic. S'ha realitzat un estudi individualitzat amb activitats del seu interès per demostrar-li que la creativitat és una peça 
fonamental en la seva vida independentment dels estudis superiors que en un futur cursi. Després d'un mes treballant amb ell, s'ha aconseguit l'objectiu plantejat, despertar la seva curiositat per fer-se preguntes i hipòtesis en les classes de ciències.

\section{METODOLOGIA}

La predisposició a aprendre de cadascun està determinada per factors culturals, personals i motivacionals. El professor ha de tenir en compte els tres factors per actuar amb la predisposició de l'alumne. Tenint en compte que el docent ha de conèixer els interessos i la motivació de l'alumnat, en aquest estudi es plantegen diverses activitats multidisciplinàries per desenvolupar la imaginació amb la finalitat d'aprendre a fer deduccions i hipòtesis en el laboratori. Per això, s'han dissenyat una bateria d'activitats basats en els seus interessos personals, entre els quals cal destacar la afició per la cuina i per la mecànica de l'estudiant. A part dels seus interessos s'ha introduït problemes de lògica $i$ raonament relacionats amb contingut científic.

Aquestes activitats s'han realitzat durant l'horari escolar, generalment en les hores d'esbarjo o de tutoria, de forma individualitzada. Setmanalment s'acordava amb l'alumne la quantitat d'activitats a executar depenent dels exàmens i tasques que tingués l'individuo aquella setmana i s'enviaven per correu electrònic al docent o es comentaven en la propera sessió assignada.

\section{RECURSOS}

Les activitats desenvolupades van ser inspirades a partir de la creativitat i innovació del docent i a partir de recursos bibliogràfics. Prèviament es va demanar un breu escrit sobre les intervencions que hauria de fer el docent per ajudar al cas estudiat en el seu rendiment acadèmic, especialment en ciències. En l'escrit constava que ell volia aprendre a fer hipòtesi i deduccions. L'alumne creia que la seva falta d'imaginació era la causant dels problemes que li suposava plantejar una hipòtesi o deducció. Així que a partir del breu escrit es va estudiar com es podia impulsar la seva creativitat. Primerament, es va plantejar una situació problema contextualitzat en una festa: Imagina't que fas una festa a la teva casa i has de refredar les begudes al més aviat possible, com ho faries: amb una galleda plena de gel i aigua o amb una galleda plena de gel, aigua i sal?

Un altre factor a analitzar va ser la comprensió lectora de l'alumne. A partir d'una entrevista troba- da casualment a la premsa, "Veure és imaginar" (Gómez, 2014) i d'un article "El arte culinario empieza en el plato" (Gordinier, 2014), vaig pensar que serien bons recursos per mostrar-li que a partir de la imaginació es poden crear coses veritablement útils, visuals i aplicables en el nostre dia a dia.

Posteriorment es van plantejar uns problemes de lògica. En total van ser quatre problemes distribuïts en dues sessions de 30 minuts cadascuna. L'alumne havia de resoldre'ls en veu alta per analitzar els seus raonaments. Els problemes de la primera tanda (Romo Santos, 1987) molt més generalitzats i no tan específics al seu interès es podien solucionar mitjançant recursos matemàtics $i$ imaginant-se l'interior de cada objecte :

- Un home va sortir a caçar un ós un dia. Va deixar el seu campament i va caminar 10 milles cap al sud, després 10 milles a l'oest, on va matar un ós. En tornar al campament va fer una distància exacta de 10 milles. De quin color era l'ós? Per què?

- Quin d'aquests cinc objectes podria servir millor per confeccionar una agulla? a) una ceba b) un peix c) un llibre d) una roda e) un clavell.

Per altra banda, els problemes restants es va plantejar un cas contextualitzat en una situació freqüentment habitual en un centre de secundària, titulat Un problema de mal de cap. Amb aquest cas, es pretenia que l'alumne fos capaç de dissenyar un experiment per confirmar o desmentir la seva hipòtesi prèviament formulada. Els altres problemes d'aquesta segona tanda van ser aplicats a la mecànica i aeronàutica. El problema de mecànica va ser inspirat en una construcció Lego que simulava una granota. D'altra banda, el problema d'aeronàutica es va basar en el test de Planning Air Maneuvers [1], on el subjecte ha d'indicar la ruta més eficaç que ha de seguir un avió de reacció per dibuixar una combinació donada per lletres en el cel per exemple les lletres L i Z.

En la següent sessió, es va canviar radicalment d'activitat, deixant a un costat els conceptes més numèrics per donar pas al desenvolupament de la creativitat a partir de la construcció d'un conte. Mitjançant un joc de daus, on en cada cara del dau hi ha un dibuix, s'ha d'elaborar una historieta on aparegui cada dibuix que ha sortit com a resultat de llançar els daus. Aquesta activitat és molt senzilla de realitzar i no requereix de molt temps, a més és aplicable a qualsevol edat i matèria. 
Per finalitzar la meva intervenció, es va preguntar al noi quins ingredients portava el seu entrepà. Una vegada escrita aquesta llista, calia que per a la següent sessió portés els ingredients anotats. El dia de la sessió la tasca de l'estudiant va ser preparar un esmorzar utilitzant tots els ingredients però sense preparar un entrepà.

\section{RESULTATS}

Després de realitzar les diverses activitats tenint en compte els interessos de l'alumne i englobant diverses competències, s'extreuen els següents resultats.

Segons la Taula 1, on apareixen les activitats desenvolupades ordenades cronològicament el percentatge de motivació, coneixement i el grau de satisfacció han augmentat des de la primera activitat "La festa" fins a "Un esmorzar especial". Aquests ítems de la taula 1 s'han calculat a partir de la valoració personal i subjectiva de l'alumne mitjançant una graella de valoració (\% motivació i grau satisfacció), mentre que el \% coneixement s'ha obtingut a partir dels resultats quantitatius obtinguts en cada activitat, on es puntua amb una escala de percentatge.

\begin{tabular}{|c|c|c|c|}
\hline Activitat & 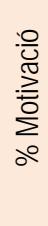 & 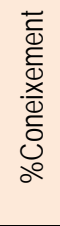 & 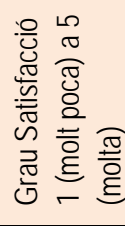 \\
\hline Problema festa & 60 & 30 & 4 \\
\hline Article el País & 30 & 40 & 3 \\
\hline Entrevista Vanguardia & 55 & 70 & 4 \\
\hline Joc Daus & 60 & 70 & 4 \\
\hline Resolució Probl Sessió 1 & 40 & 50 & 3 \\
\hline Resolució Probl Sessió 2 & 80 & 80 & 4 \\
\hline Disseny Experimental & 70 & 80 & 5 \\
\hline Esmorzar especial & 70 & 90 & 5 \\
\hline
\end{tabular}

Taula 1. Anàlisi del percentatge de motivació, coneixement i satisfacció de l'alumne segons l'activitat exercida.
L'evolució de l'estudiant va ser significativament notable. En iniciar la intervenció l'alumne no tenia cap interès per fomentar la seva capacitat d'imaginació ja que la considerava inútil i insignificant en la seva vida. No obstant això a partir de trobar-se amb problemes que solament podia resoldre mitjançant la creativitat, va arribar a reconèixer que és una capacitat i requisit per a qualsevol formació.

En les pràctiques de ciències en el laboratori es va veure una progressió de la formulació d'hipòtesi i deduccions de l'alumne una vegada finalitzada la meva intervenció. El desenvolupament de la imaginació de l'estudiant li ha facilitat l'elaboració d'un disseny experimental a partir d'una hipòtesi plantejada. A més ha fomentat la seva autoestima, seguretat, motivació i interès per la matèria impartida. Tal com es pot observar en la següent gràfica, l'evolució en auge de la creativitat ha augmentat el percentatge de l'alumne a formular hipòtesi i les seves qualificacions en ciències. Aquests resultats s'han obtingut a partir de les avaluacions que s'han realitzat durant la meva intervenció. El blau es representa el percentatge d'encerts quan fa hipòtesis $y$ en vermell la mitjana dels seus resultats acadèmics. Com mostra el gràfic, el subjecte fa més hipòtesis correctes que abans (increment d'un 12\%) amb un encert que poc a poc ha anat incrementant. Pel que fa als resultats acadèmics han millorat des de que el noi està més predisposat a formular hipòtesis.

Un clar exemple de la seva evolució sobre el seu plantejament d'hipòtesis podria ser el que es mostra a la taula 2, on s'exemplifica una hipòtesis abans i després de la intervenció sobre l'acidesa de les fruites, responent a la següent pregunta: Què és més àcid la llimona o la taronja?

\begin{tabular}{|l|l|}
\hline Hipòtesis Abans Intervenció & Hipòtesis Després Intervenció \\
\hline La llimona perquè és més àcida & $\begin{array}{l}\text { Potser que la llimona sigui més } \\
\text { àcida que la taronja per els com- } \\
\text { ponents que la composen, potser } \\
\text { la llimona té més compostos cí- } \\
\text { trics que la taronja. }\end{array}$ \\
\hline
\end{tabular}

Taula 2. Hipòtesis abans i després de la intervenció. L' hipòtesis d'abans es veu clarament que és una afirmació sense una justificació adient, metre que després de la intervenció, es mostra una hipòtesis més elaborada. 


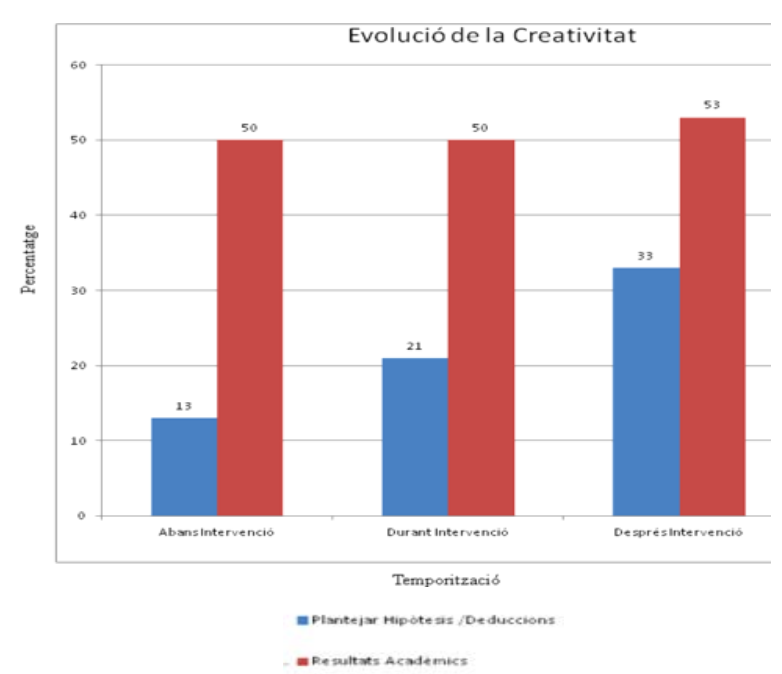

Figura 1. Representació en barres de l'evolució de l'alumne alhora de plantejar hipòtesis i la relació amb els seus resultats acadèmics.

\section{CONCLUSIONS}

Amb aquest estudi es pot concloure que la imaginació és una capacitat adaptable, és a dir, no es neix creatiu, ets fas. En el cas analitzat a mesura que s'han avançat en les sessions, la creativitat del subjecte ha anat en augment de forma gradual però constant. Per tant es mostren diferents recursos per fomentar aquesta capacitat i obtenir millors resultats acadèmics en ciències, ja que promoure la imaginació, permet tenir un ventall més ampli de situacions que pensar.

Es diu que els ulls són un dispositiu per veure com és allò que ens envolta i com són els altres. Però... i per mirar endins d'un mateix? En aquest sentit, com a cecs. O bé passa que tot el que veiem fora és, en realitat, la qual cosa portem endins? Llavors, no ens hauria d'estranyar que existeixin tantes desgràcies. D'una manera o una altra només veiem la meitat del que hi ha, o sigui que dos ulls o són massa o són poc, però mai la mesura justa. És un motiu poderós per afirmar que no és que la naturalesa sigui sàvia sinó que sap nombroses coses de memòria i les repeteix com un lloro.

La meva intervenció amb l'estudiant, és desmentir que la naturalesa és sàvia per saber infinitats de coses recordades en la memòria, ja que a part d'activar els nostres records és necessària l'activació de la nostra creativitat. Amb aquest estudi, s'ha pogut veure una progressió lenta però efectiva en la imaginació d'un subjecte, es confirma, doncs, que fomentar la imaginació de l'alumnat afavoreix la motivació i l' interès per la matèria a impartir, obtenint generalment, millors resultats acadèmics.

El conjunt d'aquestes activitats ha beneficiat a concloure que la imaginació és com un auxiliar útil de la ciència, no només perquè inspira les seves hipòtesis al savi, en la teoria, sinó també perquè li suggereix les invencions en la pràctica. Les aplicacions de la ciència són amb freqüència resultat d'una deducció raonada o del desenvolupament lògic de la teoria, però en més d'un cas la imaginació col.labora a aquest treball.

\section{BIBLIOGRAFIA I REFERÈNCIES}

GÓMEZ, X. Veure-hi és imaginar. La Vanguardia, La Contra, 17 de Gener del 2014

GORDINIER, J. El arte culinario empieza en el plato. El País, 16 de Gener del 2014.

ROMO SANTOS, M.(1987) Treinta y cinco años del pensamiento divergente: teoría de la creatividad de Guilford. Universidad Autónoma de Madrid.

[1] Test de Planning Air Maneuvers. Air Force. 